\title{
Trypanosoma (Herpetosoma) mariae n. sp., isolated from Calomys callosus Rengger, 1830 (Rodentia-Cricetinae) *
}

\author{
by D.A. MELLO \\ Faculty of Health Sciences \\ University of Brasilia, Brasilia, F.D. Brazil.
}

\section{Summary.}

In the present paper a new trypanosome species of the subgenus Herpetosoma, isolated from a wild rodent, is described, and named Trypanosoma (Herpetosoma) mariae. Some biological aspects of this species were studied.

\section{Résumé.}

Trypanosoma (Herpetosoma) mariae n. sp., parasite du rongeur Calomys callosus, Rengger, 1830.

Description d'une nouvelle espèce de Trypanosomatidae, Trypanosoma (Herpetosoma) mariae, provenant du sang d'un Calomys callosus Rengger, 1830 (Rodentia-Cricetinae). Quelques aspects de la biologie de $T$. mariae ont été étudiés.

\section{Introduction}

Several species of Tryponosomatidae of the Herpetosoma subgenus have been found in many rodent species (Hoare, 1972 and Molyneux, 1976).

In Brazil, five species of Herpetosoma subgenus have been described from rodents (Carini and Maciel, 1915, Artigas and Pacheco, 1934, Deane 1961, Coutinho and Pattolli, 1964).

* This work was supported, in part, by a grant of National Research Council of Brazil (SIP/08-032-CNQq 6228/75), and the Ministry of Health.

Accepté le 20 février 1978. 
In this paper, a new trypanosome species of the subgenus Herpetosoma is described The parasite is named Trypanosoma (Herpetosoma) mariae sp. $\mathrm{n}$. in honour of the Brazilian parasitologist, Professor Maria Paumgartten Deane.

\section{Material and methods}

During a survey of wild reservoirs of Trypanosoma cruzi in the northern part of the Formosa county, state of Goiás, Brazil, a specimen of the rodent Calomys callosus was found naturally infected with a flagellated protozoan belonging to the subgenus Herpetosoma.

The infected $C$. callosus was captured in September 22, 1976 and examined the following day. Fresh blood from the tail was examined under the microscope. Thin smears from the blood were made and stained with the Giemsa-Romanovsky method, and from them 40 trypanosomes were drawn and measured with the aid of the camera lucida. The measurments of the drawings were made at a magnification of $1,200 \mathrm{x}$. Photographs were taken at a magnification of $700 \mathrm{x}$.

Five $C$. callosus bred in laboratory, five white rats (Rattus norvegicus), five white mice (Mus musculus), five hamsters (Mesocricetus auratus), five Oryzomys eliurus, two Cercomys cuincularius and two guinea-pigs (Cavia aperea) were injected intraperitoneally with $0.1 \mathrm{ml}$. of the blood from the infected rodent. The blood of the animals was examined on alternate days from the 5 th day after inoculation until the 30 th day. Xenodiagnosis, utilizing nymphs of I an IV stages of Rhodnius neglectus, Panstrongylus megistus and Triatoma infestans, were made on the original infected $C$. callosus, and on all the other experimental rodent.

Fragments of heart, thigh muscle, œsophagus and colon from inoculated animals (sacrificed 90 days after inoculation), were fixed in $10 \%$ formaldehyde for histological examination. The sections were stained with haematoxylin and eosin.

Two attempts to infect fleas, Xenopsylla cheopis and Polygenys jordani, were made. The fleas were from a laboratory colony maintained at the Plague Laboratory of the Ministry of Health, Garanhuns, State of Pernambuco, Brazil. The first attemp to infect the fleas was made placing 21 fleas of each species on $C$. callosus experimentally infected with $T$. $(H$.) mariae and having a high parasitaemia. Ten hours after exposure to the infected rodents, the fleas were removed and one specimen of each species was examined immediately by dissecting the alimentary tract. The other fleas were examined on the same day after removal from the infected rodent at intervals between 6 to 10 hours, until 53 hours. A second attempt to infect fleas was made on the same way but the exposure of fleas on infected rodents was for three hours. One specimen of each species was then examined for infection. Eight hours later, one of each flea species was crushed in saline and inoculated in two laboratory reared $C$. callosus. These animals were examined for infection five days after the inoculation. Another two laboratory reared $C$. callosus were exposed to fleas which had been permitted to feed for three hours on infected C. callosus. 
Attemps to culture the flagellates from infected blood were made on LIT and $\mathrm{NNN}$ media at $36^{\circ} \mathrm{C}$. $28^{\circ} \mathrm{C}$. and room temperature averaging $23^{\circ} \mathrm{C}$.

\section{Results}

By direct microscope examination of the original infected C. callosus blood, high parasitemia of trypomastigote forms was observed. The characteristics of the flagellate, in stained blood smears, are shown in figure 1 and figure 2.

The morphological qualitative description of the new trypanosome found in the blood of $C$. callosus is as follows:

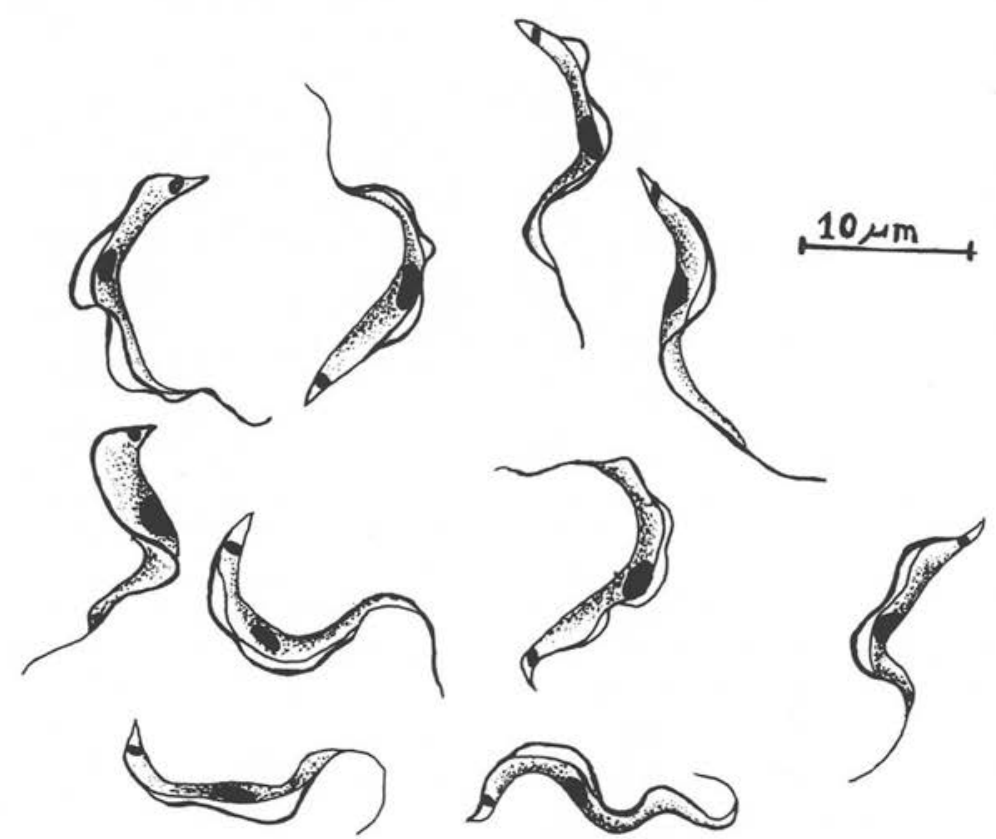

Fig. 1. Trypanosoma (Herpetosoma) mariae n. sp. from the blood of the rodent Calomys callosus (x 1.200).

The trypanosomes in the stained blood smears have a slender body and generaly appear in $« C$ » or $« S$ » shape. Only trypomastigotes forms were found in the stained preparations. The kinetoplast is large and round or oval-shaped. It lies nearer to the posterior than the anterior extremity. The nucleus is oval and frequently slightly anterior to the middle of the body. The undulating membrane has 3-4 clear folds.

The measurements taken from $40 \mathrm{~T}$. mariae in blood smears of the original infected rodent are shown in Table 1 in comparison with $T$. forattini and $T$. renjifori. 
Attempts to infect white rats, mice, hamsters, guinea-pigs and Cercomys cunicularius with blood forms failed. However, two $O$. eliurus showed fleeting low parasitemias, on days 10 and 12 .

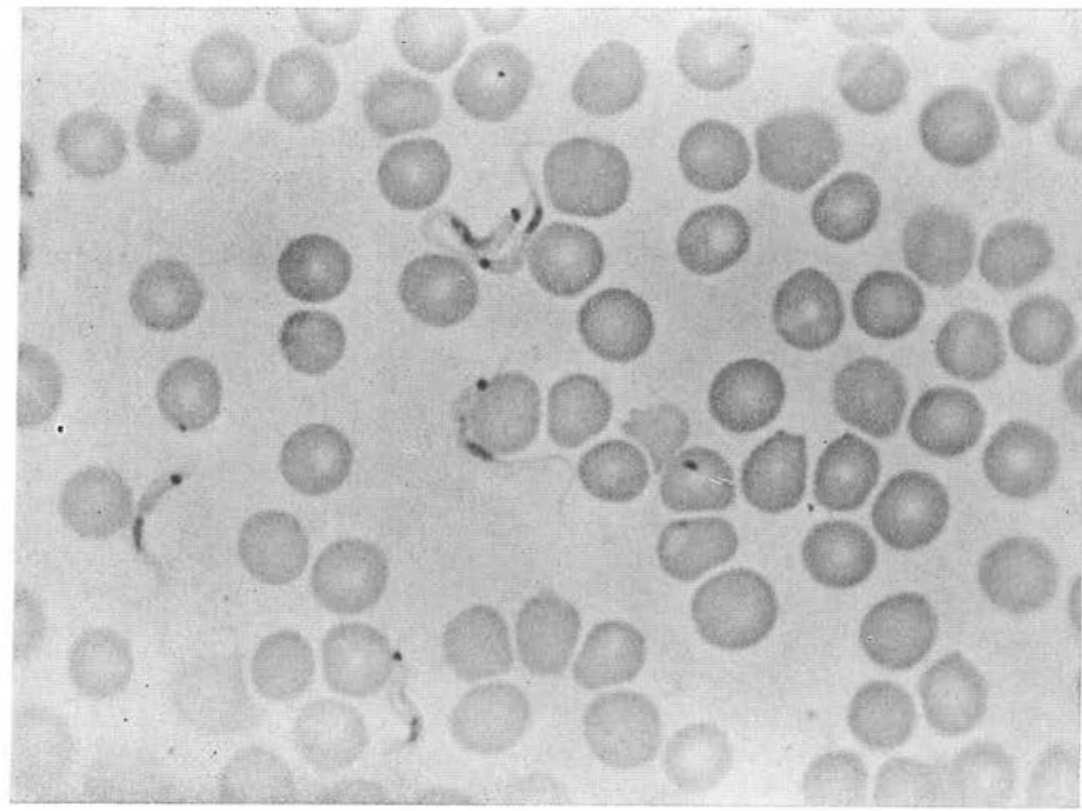

Fig. 2. Photomicrograph of trypomastigote forms of Trypanosoma (Herpetosoma) mariae from blood smears of infected Calomys callosus. (700x).

All experimentally inoculated $C$. callosus became infected. They showed high parasiteamias which disappeared between 45 to 60 days after inoculation.

Results from all xenodiagnosis were negative. Histologic results were also negative for the presence of parasites or tissue reactions.

Attempts to infect the fleas gave the following results:

1st attempt: - Trypanosomes were found only in fleas which were dissected three hours after removal from the infected animals. Trypomastigotes and dividing epimastigotes forms were seen in the intestine and rectum.

2nd attempt: - All the specimens of $C$. callosus inoculated with fleas which had fed on the original infected rodent became infected. The blood of the specimens of C. callosus which were exposed to the fleas fed on the infected rodent remained negative.

From attempts to culture $T$. $(H$.) mariae it was found that this trypanosome does not grown easily on artificial media. Positive culture was obtained only on LIT medium at room temperature and $28^{\circ} \mathrm{C}$., but only few epimastigotes and trypomastigotes were seen on the medium on the 6 th-7th days after the incubation. 


\section{Comments and conclusions}

With the exception of $T$. cruzi, very little is known about the trypanosomes of Brazilian rodents.

Carini and Maciel (1915) described a new species, T. akodoni, from the rodent Akodon fuliginosus, pointing out the morphological similarity of this trypanosome to $T$. cruzi. They were unable to infect laboratory mammals usually susceptible to T. cruzi.

Artigas and Pacheco (1934) found a lewisi-type trypanosome in the blood of Myocastor coypus from Brazil. The total length of this parasite was $31 \mu \mathrm{m}$.

A new species of trypanosome, of the group lewisi, T. renjifoi, was identified by Deane (1961) from the rodent Proechimys guyannensis. This author experimentaly inoculated blood forms of $T$. renjifoi in rats, mice, guinea-pigs and $P$. guyannensis. Only the last animal became infected, this gave strong evidence of the host restriction of $T$. renjifoi. Coutinho and Pattolli (1964) found $O$. eliurus naturally infected with a new species of the lewisi group, named $T$. forattini. Another new species, $T$. deanei, was identified by the above authors from Oxymycterus quaestor.

However, Ribeiro and Barreto (1972 and 1972 a) commenting on the findngs of Carini and Maciel (1915) and Coutinho and Pattolli (1964), judiciously placed the species $T$. akodoni and $T$. deanei as synonyms of $T$. cruzi.

From several experiments on the biology of $T$. foratini, isolated from $O$. capito captured in the forest Turure in Trinidad, Everard and Souza (1972) concluded that this species belongs to the lewisi group and shows a high specificity for its mammalian host.

As far as is known, the majority of the species of the subgenus Herpetosoma develop in the alimentary tract of Siphonaptera. Results obtained in the present paper were not sufficiently clear-cut to incriminate $X$. cheopis and $P$. jordani as vectors of $T$. mariae. However, $P$. jordani is a common ectoparasite of $C$. callosus.

The results obtained with «in vitro» cultures, using LIT medium, were similar to those mentioned by Molyneux (1976). According to this author, blood stream forms of lewisi group trypanosomes are less easily cultured «in vitro» than the vector forms.

The trypanosome described in the present paper belongs undoubtedly to the lewisi group (Hoare, 1972). Two other species of trypanosomes of this group in Brazilian rodents are T. renjifoi (Deane, 1961) and T. forattini (Coutinho and Pattolli 1964). These two species have been identified on the basis of host, specifity and experimental inoculations (Deane, 1961, Everard and Souza, 1972). The biology of lewisi-like trypanosomes, especially the life-history and host-specificity, is recognized as important in distinguishing species of lewisi like trypanosomes (Davis, 1952, Molyneux, 1976).

In table 1, measurements of $T$. mariae, T. renjifoi and $T$. forattini are presented which are sufficiently great for the morphological separation of $T$. mariae from the two other species. Results of the experimental inoculations suggest a high degree 
of host specificity of $T$. mariae and support the specific validity of the trypanosome described on this paper.

Table 1. Comparative measurements of T. (H.) mariae n.sp., T. (H.) reniifoi and T. (H.) forattini

\begin{tabular}{|c|c|c|c|}
\hline $\begin{array}{l}\text { Measurements } \\
\quad \text { (um) }\end{array}$ & $\begin{array}{l}\text { T. mariae } \\
\text { n. sp. }\end{array}$ & $\begin{array}{c}\text { T. renjifoi } \\
\text { Deane, } 1961\end{array}$ & $\begin{array}{c}T . \text { forattini } \\
\text { Coutinho et al. } \\
1964\end{array}$ \\
\hline Total length $\ldots \ldots \ldots \ldots \ldots \ldots \ldots \ldots \ldots \ldots \ldots \ldots \ldots \ldots$ & $21.4(\mathrm{sd} \pm 1.9)$ & 28.1 & 31.4 \\
\hline Distance from posterior end to kinetoplast .. & $0.9(\mathrm{sd} \pm 0.3)$ & 3.3 & 2.2 \\
\hline Distance from kinetoplast to middle of nucleus & $7.7(\mathrm{sd} \pm 1.2)$ & - & 8.6 \\
\hline Distance from nucleus to anterior end $\ldots \ldots$. & $6.8(\mathrm{sd} \pm 1.1)$ & 6.0 & - \\
\hline $\begin{array}{l}\text { Distance from posterior end to middle of } \\
\text { nucleus } \ldots \ldots \ldots \ldots \ldots \ldots\end{array}$ & $4.9(\mathrm{sd} \pm 0.9)$ & 8.8 & 6.3 \\
\hline Free flagellum $\ldots \ldots \ldots \ldots \ldots \ldots \ldots \ldots$ & $4.5(\mathrm{sd} \pm 1.7)$ & 10.2 & 12.1 \\
\hline Nuclear length $\ldots \ldots \ldots \ldots \ldots \ldots \ldots \ldots$ & - & 2.2 & - \\
\hline 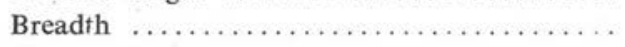 & $1.4(\mathrm{sd} \pm 0.3)$ & 1.7 & 2.1 \\
\hline Nuclear index $\ldots \ldots \ldots \ldots \ldots \ldots \ldots \ldots$ & 1.57 & - & - \\
\hline Kinetoplastic index $\ldots \ldots \ldots \ldots \ldots \ldots \ldots$ & 1.13 & 一 & 1.36 \\
\hline
\end{tabular}

\section{Bibliographie}

Artigas P. de T., Pacheco G. (1934): Trypanosoma myocastori n. sp. - parasito de Myocastor coypus. Ann. Fac. Med. Univ. S. Paulo, 10, 317.

Carini A., Maciel J. (1915): Sur une hémogregarine et un trypanosome de Muridé (Akodon fuliginosus) Bull. Soc. Pathol. Exot., 8, 165-169.

Coutinho J. de O., Pattolli D. (1964): Contribuljao para o conhecimento dos tripanosomos de roedores, com a descriçao de duas novas espécies. Pap. Avul. Dept. Zool. Sec. Ag. S. Paulo, $16,217-227$.

Davis B. S. (1952): Studies on the trypanosomes of some California mammals. Univ. Calif. Publ. Zool. 57, 145-250.

Deane L. M. (1961): Tripanosomideos de Mamiferos da Regiao Amazônica. I. Alguns flagelados encontrados no sangue de mamíferos silvestres do estado do pará. Rev. Inst. Med. Trop. Sao Paulo, 3, 15-28.

Everardo C. O. R., Souza O.E. (1972) : Recovery of Trypanosoma forattinni Coutinho and Pattolli, from a Trinidian rodent. Rev. Saûde Publi. S. Paulo, 6, 283-285.

Hoare C.A. (1972): The Trypanosomes of Mammals. A Zoological Monograph. Blackwell Scientific Publications, Oxford, 749 p.

Molyneux D.H. (1976) : Biology of the Kinetoplatida, vol, 1. Edited by W.H. R. Lumsden and D. A. Evans. Academic Press, London.

Ribeiro R. D., Barreto M.P. (1972): Estudos sobre reservatôrios e vectores silvestres do Trypanosoma cruzi XLIX: Sinonîmia do Trypanosoma akodoni Carini e Maciel, $1915 \mathrm{em}$ T. cruzi Chagas, 1909. Rev. Inst. Med. Trop. S. Paulo, 14, 162-170.

Ribeiro R. D., Barreto M.P., (1972a) : Estudos sobre reservatórios e vectores silvestres do Trypanosoma cruzi. L. Sobre a sinomínia de Trypanosoma deanei Coutinho et Pattolli, $1964 \mathrm{em}$ Trypanosoma cruzi Chagas, 1909. Rev. Bras. Biol., 32, 105-111. 